\title{
Performance of Regional Rural Banks after Amalgamation in India: Progress and Prospects
}

\author{
Tasleema M Jorum* and Sujata S Mali ${ }^{\dagger}$
}

\begin{abstract}
For the past three decades India's banking system has several outstanding achievements to its credit. The most striking is its extensive reach. It is no longer confined to only metropolitans or cosmopolitans in India. In fact, Indian banking system has reached even to the remote corners of the country. This is one of the main reasons for India's growth process. The government's regular policy for Indian banks since 1969 has paid rich dividends with the nationalization of 14 major private banks of India. Regional Rural Banks started their development process on 2 October 1975 with the formation of a single bankPrathama Grameen Bank. The RRBs mobilize financial resources from rural/semi-urban areas and grant loans and advances mostly to small and marginal farmers, agricultural labourers and rural artisans. The area of operation of RRBs is limited to the area as notified by GoI covering one or more districts in the State. In this context, the present study is an attempt to examine the impact of amalgamation on physical performance of RRBs during post-amalgamation period.
\end{abstract}

Keywords: Banking; Regional rural banks; Amalgamation; Profit and loss and economic development; NPAs and deposits.

\footnotetext{
* Assistant Professor, S. S. G. F. G. College, Nargund

† Lecturer, P. G. Department of Economics, Mount Carmel College, Bangalore; surysujata@gmail.com
} 


\section{Introduction}

India's banking system has several outstanding achievements to its credit. It is no longer confined to only metropolitan, but it has reached even to remote areas. The first bank in India was established in 1786 called 'The General Bank of India'. The East India Company established Bank of Bengal (1809), Bank of Bombay (1840) and Bank of Madras (1843). These three banks were amalgamated in 1920 and Imperial Bank of India was established which started as private shareholders banks, (mostly Europeans shareholders). In 1865, Allahabad Bank was established, exclusively by Indians. Reserve Bank of India (RBI) came in 1935. There were approximately 1100 banks during 1913-1948. To guideline the activities of commercial banks, the government of India came up with Banking Regulation Act 1949 and RBI was vested with extensive power for the supervision of banking in India as the Central Banking Authority. During those days public had lesser confidence in the banks. In 1955, it nationalized Imperial Bank of India to extend banking facilities to rural and semi-urban areas. It formed State Bank of India to act as the principal agent of RBI and to handle banking transactions of the Union and State Governments all over the country. Seven banks forming subsidiaries of State Bank of India was nationalized in 1960 on 19 July, 1969, major process of nationalization was carried out and RRB Act was passed in 1975 to establish RRBs to provide banking facilities to the rural and agriculture sector. After nationalization of banks the branches of public sector banks in India rose to $88 \%$ in deposits and $11000 \%$ in advances. Government of India has taken steps to allow foreign banks to establish their branches in India and their ATMs. Efforts are being taken to give satisfactory service to customers; phone banking and net banking is introduced.

During post-reform period, as per the recommendations of the Narasimhan committee, restructuring of the banking system, deregulation of interest rates; abolition of licensing and enhancement of capital base stock lead to positive growth. An improvement in performance of Banks has taken place and that contributes to development of banking sector in India. But in 200910 there was slow down in the balance sheet growth of scheduled commercial banks. In general banks have had a track record of 
innovation, growth and value creation. However, this process of banking development needs to be taken forward to serve the larger need of financial inclusion through expansion of banking services.

\section{Regional Rural Banks}

Banking activities are an important link among the various economic activities and that have to play a vital role. India is agriculture-based country where more than $60 \%$ of the people live in rural area, and only depend on agriculture. Initially commercial banks had opened their branches in rural areas to provide agriculture finance, but failed to fulfil the objectives with which they were brought in the field. It was observed that commercial banks in rural area, instead of providing credit facility to poor, concentrated upon the big landholders and mobilize the savings of richer sections of the society. Consequently, it was felt that the specialized financial institutions should be established to mobilize the savings and to meet the financial needs of rural people. Accordingly, as per the recommendations of Narasimhan Committee, first five Regional Rural Banks (RRBs) were established on $2^{\text {nd }}$ October 1976, with the objective to ensure sufficient institutional credit for agriculture and other rural sectoRs The RRBs mobilize savings from rural/semi urban areas and grant loans and advances to small, marginal farmers, agricultural labourers and rural artisans. These banks instil banking habits among the rural people, provide capital assistance to targeted group and made banking service made accessed by rural poor. RRBS jointly owned by GOI, State government and sponsor banks. The capital of RRBs subscribed by the owner in the proportion of 50:15:35 respectively.

Over the years, RRBs emerged as a key rural financial institution in terms of geographical coverage, clientele outreach and business volume. From a modest beginning of 6 RRBs with 17 branches covering 12 districts in December 1975, the number of RRBs has grown into 196 RRBs with 14,446 branches working in 518 districts across the country in March 2004 (just before the amalgamation process). As on March 2009, RRBs have a large branch network in the rural area forming around 37 percent of the total rural branches of commercial banks. The rural orientation of RRBs is evident from the fact that their rural and semi-urban branches constituted over 
95 percent of their branch network. The high-powered Committee on the Financial System was constituted by GOI to examine all the aspects relating to the structure, organization, functions and procedure of the financial system (Narasimham Committee, 1998) underscored the commendable progress made by the Indian banking sector in extending its geographical spread and its function/operations and thereby promoting financial intermediation and growth in the economy. However, the committee cautioned that unless the deterioration in the financial system was treated quickly, it could further erode the real value of and end return on the savings entrusted to it and even have an adverse impact on depositor's and investor's confidence. In addition, possibly, financial repression involving state-owned banks was not in harmony with agenda of real sector reforms that the GOI unleashed in the aftermath of the balance of payment crises of 1991. (RBI), therefore, initiated reform of the banking sectors in 1992 based on the recommendations of Narasimham Committee I (Ram Mohan, 2007. As a part of the downsizing process of the public sector organizations, the GOI in consultation with sponsor banks and the National Bank for Agriculture and Rural Development (NABARD) took a decision to amalgamate the 196 RRBs. The process of amalgamation resulted into reduction in number of RRBs from 196 RRBs to 89 RRBs in March 2008. As a result of amalgamation of RRBs, as on March 2011, there were 82 RRBs with 15938 branches working across the country.

\section{Amalgamation}

In order to improve the operational viability of RRBs in India and take the advantage of economies of scale, the advisory committee under the chairmanship of V. S. Vyas was formed. The internal working group on RRBs was set up by the RBI to examine the various alternatives available within the legal framework for strengthening the RRBs in consultation with NABARD and concerned state government. To reposition RRBs as an effective instrument of credit delivery in Indian financial system, the committee had suggested structural consolidation of RRBs (Amalgamation). 
More recently, during 2005, a committee under the chairmanship of Prof. A.V. Sardesai held that 'to improve the operational viability of RRBs and take the advantage of economies of scale 'amalgamation may be of two ways:

1) Amalgamation between the RRBs of the sponsor bank in the same state (Horizontal Merger).

2) Amalgamation of RRBs with sponsor bank in the same state (Vertical Merger).

According to this the first way was followed in 2005. As result of this the number of RRBs reduced to 133 from 196 and expected to cover wider area, more small and marginal farmers, landless labourers and rural artesian.

\section{Methodology}

The present is based on secondary data, relating to the all India level. The time period covered is from 2005-2010. Data has been collected from various secondary sources like RBI Report on trend \& progress of Banking in India, NABARD Annual report etc. Data is analysed using the various statistical techniques like percentage, growth rate etc. This study aims to examine the physical performance of RRBs based on physical parameters i,e. in terms of; Growth of RRBs in terms of the physical and financial growth of RRBs, the advances by the RRBs in different sections and the recovery performance of NPAs.

\section{Results and Discussions}

The physical performance of the RRBs was analyzed and interpreted by using the following parameters:

\section{Key Performance Indicators of RRBs}

From the above Table-1, it is revealed that, with the amalgamation process number of RRBs has come down to 82 at the end of 2011, with 15938 branches. As far as the profitability was concerned, net profit for the year 2011 was 38\% more than the previous year. Accordingly the volume of business (deposit + advance) of RRBs for 2006 was Rs109849 crore and it increased to Rs267271 crores for 2011. 
Table 1: Key Performance Indicators of RRBs (2005-06 to 2009-10 - Rs in crore)

\begin{tabular}{|l|l|l|l|l|l|l|}
\hline \multirow{2}{*}{ Indicator } & \multicolumn{6}{|c|}{ Year } \\
\cline { 2 - 7 } & $2005-06$ & $2006-07$ & $2007-08$ & $2008-09$ & $2009-10$ & $2010-11$ \\
\hline No of RRB's & 133 & 96 & 90 & 86 & 82 & 82 \\
\hline No of Branches & 14,494 & 14,520 & 14,761 & 15,235 & 15,444 & 15938 \\
\hline $\begin{array}{l}\text { Net profit } \\
\text { crores) }\end{array}$ & 617 & 625 & 1328 & 1712 & 2509.18 & 3464.82 \\
\hline Share capital & 196 & 196 & 197 & 197 & 197 & 197 \\
\hline Reserve & 4270 & 4901 & 5703 & 6150 & 712 & 9,582 \\
\hline Deposits & 71,329 & 83,144 & 99,093 & $1,20,189$ & $1,45,035$ & $1,66,232$ \\
\hline Borrowing & 7302 & 9775 & 11474 & 12250 & 18555 & 26,491 \\
\hline $\begin{array}{l}\text { Loans \& } \\
\text { advances }\end{array}$ & 38,520 & 47,326 & 57,568 & 65,609 & 79,157 & 101039.30 \\
\hline Investment & 41182 & 45666 & 48559 & 51159 & 76167 & 95245.99 \\
\hline $\begin{array}{l}\text { Accumulated } \\
\text { loss }\end{array}$ & 2637 & 2760 & 2624 & 2574 & 1813 & 1366.80 \\
\hline Networth & 4009 & 4526 & 6107 & 6750 & 10256 & 12566.52 \\
\hline Net NPA (\%) & 3.96 & 3.46 & 3.4 & 1.8 & --- & -- \\
\hline $\begin{array}{l}\text { Branch } \\
\text { productivity }\end{array}$ & 7.7 & 9.1 & 10.7 & 12.05 & 12.17 & \\
\hline $\begin{array}{l}\text { Staff } \\
\text { productivity }\end{array}$ & 1.6 & 1.9 & 2.3 & 2.7 & $\ldots$ & \\
\hline
\end{tabular}

Source; RBI Report on trend \& progress of Banking in India

The borrowing for 2006 was Rs 7302 crores, which was increased to Rs 26,491 crores for 2011. The accumulated loss came down to Rs 1366.80 crores from Rs 1813 crores for 2010 .The net worth of RRBs for the year 2011 was Rs 12566.52 crores and branch productivity to $12.17 \%$. The net NPA (\%) reduced to $1.8 \%$ from $3.96 \%$. Thus it was observed from this, that the amalgamation process helps to improve the operational efficiency and take the advantage of economies of scale.

\section{Regionwise Profit Making and Loss Making of RRBs}

The present data on the performance of RRBs region wise in India in terms of profit making and loss making units is presented in Table-2.

As per the recommendations of Narsimhan committee structural consolidation of RRB's, the number of RRBs reduced to 82 in the year 2010 from 133 banks in the year 2006. Table- 2 shows the region-wide spread of RRBs from 2006 to 2010 and makes region wise comparison between profit making and loss making units. 
Table 2: Regionwise Number of RRBs Making Profit or Loss

\begin{tabular}{|c|c|c|c|c|c|c|c|c|c|c|c|c|c|c|c|c|c|c|}
\hline \multirow[t]{2}{*}{ Region } & \multicolumn{3}{|c|}{2006} & \multicolumn{3}{|c|}{2007} & \multicolumn{3}{|c|}{2008} & \multicolumn{3}{|c|}{2009} & \multicolumn{3}{|c|}{2010} & \multicolumn{3}{|c|}{2011} \\
\hline & No & Profit & Loss & No & Profit & Loss & No & Profit & Loss & No & Profit & Loss & No & Profit & Loss & No & Profit & Loss \\
\hline NER & 8 & 5 & 3 & 8 & 5 & 3 & 8 & 5 & 3 & 8 & 7 & 1 & 8 & 7 & 1 & 8 & 7 & 1 \\
\hline Eastem & 28 & 17 & 11 & 16 & 9 & 7 & 15 & 13 & 2 & 14 & 14 & 0 & 14 & 14 & 0 & 14 & 14 & 0 \\
\hline Northem & 18 & 15 & 3 & 16 & 14 & 2 & 16 & 13 & 2 & 15 & 15 & 0 & 15 & 15 & 0 & 15 & 15 & 0 \\
\hline Central & 48 & 46 & 2 & 31 & 29 & 2 & 27 & 26 & 1 & 23 & 21 & 2 & 23 & 21 & 2 & 23 & 22 & 1 \\
\hline Westem & 11 & 8 & 3 & 10 & 9 & 1 & 9 & 9 & 0 & 6 & 6 & 0 & 6 & 6 & 0 & 6 & 6 & 0 \\
\hline Sonthem & 20 & 20 & 0 & 15 & 15 & $\mathbf{0}$ & 15 & 15 & $\mathbf{0}$ & 16 & 15 & 1 & 16 & 15 & 1 & 16 & 15 & 1 \\
\hline India & 133 & 105 & 20 & 96 & 81 & 15 & 82 & 76 & 8 & 82 & 78 & 4 & 82 & 78 & 4 & 82 & 79 & 2 \\
\hline
\end{tabular}

Source: NABARD Annual report

The percentage of profit making units for 2010 is $97 \%$, which is more than it was for the year 2006(78.94\%). The percentage of loss making units reduced to 3\% for 2011 from $15.03 \%$ in the year 2006 .

\section{Deposits}

Deposit constitutes the cheap source of finance. Hence the success of banks largely depends upon its ability to tap savings of all the sections of society and particularly in rural area.

This is because in the absence of institutional facility surplus amount can be utilized for consumption purpose, but it does not lead to economic development of country particularly in rural area.

From Table- 3, it is revealed that the percentage of growth in deposits has been decreased $14.62 \%$ during the year 2011 from $21 \%$ for the year 2010 .

Table 3: Deposits

\begin{tabular}{|c|c|c|}
\hline YEAR'S & DEPOSIT (Rs in crore) & GROWTH $\%$ \\
\hline $2005-06$ & 71,329 & 14.78 \\
\hline $2006-07$ & 83,144 & 16.56 \\
\hline $2007-08$ & 99,093 & 19.18 \\
\hline $2008-09$ & $1,20,189$ & 21.28 \\
\hline $2009-10$ & $1,45,035$ & 21 \\
\hline $2010-11$ & $1,66,232$ & 14.62 \\
\hline
\end{tabular}

Source; RBI Report on trend \& progress of Banking in India 


\begin{tabular}{|c|c|c|}
\hline YEAR'S & $\begin{array}{c}\text { LOANS \& } \\
\text { ADVANCES } \\
\text { (Rs In crore) }\end{array}$ & GROWTH \% \\
\hline $2005-06$ & 38,520 & 17.19 \\
\hline $2006-07$ & 47,326 & 22.86 \\
\hline $2007-08$ & 57,568 & 21.64 \\
\hline $2008-09$ & 65,609 & 13.96 \\
\hline $2009-10$ & 79,157 & 20.64 \\
\hline $2010-11$ & 101039.30 & 27.64 \\
\hline
\end{tabular}

Source; RBI Report on trend \& progress of Banking in India

From the above Table-4, it is found that the percentage of loans and advances for the year 2006 was $17.19 \%$ and it increased to $27.64 \%$ during the year 2011.

\section{Regionwise Loan Outstanding}

Table 5: Regionwise Loan Outstanding (in \%):

\begin{tabular}{|l|l|l|l|l|l|l|}
\hline Zone & $2005-6$ & $2006-7$ & $2007-8$ & $2008-9$ & $2009-10$ & $2010-11$ \\
\hline NER & 58.55 & 25.33 & 22.22 & 16.80 & 48.81 & -7.1 \\
\hline West & 30.69 & 14.01 & 28.91 & 22.35 & 26.22 & 1.46 \\
\hline North & 82.44 & 23.13 & 25.04 & 28.05 & 68.20 & -3.1 \\
\hline South & 19.61 & 22.67 & 19.18 & 19.98 & 35.56 & 38.34 \\
\hline Central & 88.53 & 20.65 & 24.05 & 22.92 & 33.64 & -22.94 \\
\hline East & 45.42 & 17.62 & 18.96 & 17.68 & 35.52 & -3.7 \\
\hline India & 51.82 & 20.81 & 22.11 & 21.63 & 39.40 & 3.1 \\
\hline
\end{tabular}

Source: NABARD Annual report

Table-5 indicates that the total region-wise outstanding for 2006

Source: NABARD Annual report

was $58.55 \%$, it decreased to $39.40 \%$. In case of region wise loans outstanding central Region banks have highest percentage of loans outstanding $(88.53 \%)$ and southern RRBs have lowest percentage outstanding (19\%) for 2006. But during 2011 southern banks have highest outstanding (38.34\%) and central region banks have negative loans outstanding $(-22.94 \%)$. 


\section{Priority Sector Advances:}

Table 6: Priority Sector Advances (In \%)

\begin{tabular}{|l|c|c|c|c|c|c|}
\hline \multirow{2}{*}{ Purpose } & \multicolumn{6}{|c|}{ Year } \\
\cline { 2 - 7 } & 2006 & 2007 & 2008 & 2009 & 2010 & 2011 \\
\hline & $\begin{array}{c}\text { Growth } \\
\%\end{array}$ & $\begin{array}{c}\text { Growth } \\
\%\end{array}$ & $\begin{array}{c}\text { Growth } \\
\%\end{array}$ & $\begin{array}{c}\text { Growth } \\
\%\end{array}$ & $\begin{array}{c}\text { Growth } \\
\%\end{array}$ & $\begin{array}{c}\text { Growth } \\
\%\end{array}$ \\
\hline Agriculture & 54.00 & 71 & 56.31 & 55.06 & 54.84 & 54.90 \\
\hline $\begin{array}{l}\text { Non- } \\
\text { Agriculture }\end{array}$ & 45.00 & 29 & 43.69 & 44.94 & 45.16 & 44.60 \\
\hline Total & 100 & 100 & 100 & 100 & 100 & 100 \\
\hline
\end{tabular}

Source: RBI Report on trend \& progress of Banking in India

Table 6 shows the percentage of priority sector advances by RRBS during 2006 to agriculture sector was $54 \%$ and non agriculture sector $45 \%$. For the year 2010, it increases to $54.90 \%$ for agriculture and $44.60 \%$ to non agriculture sector.

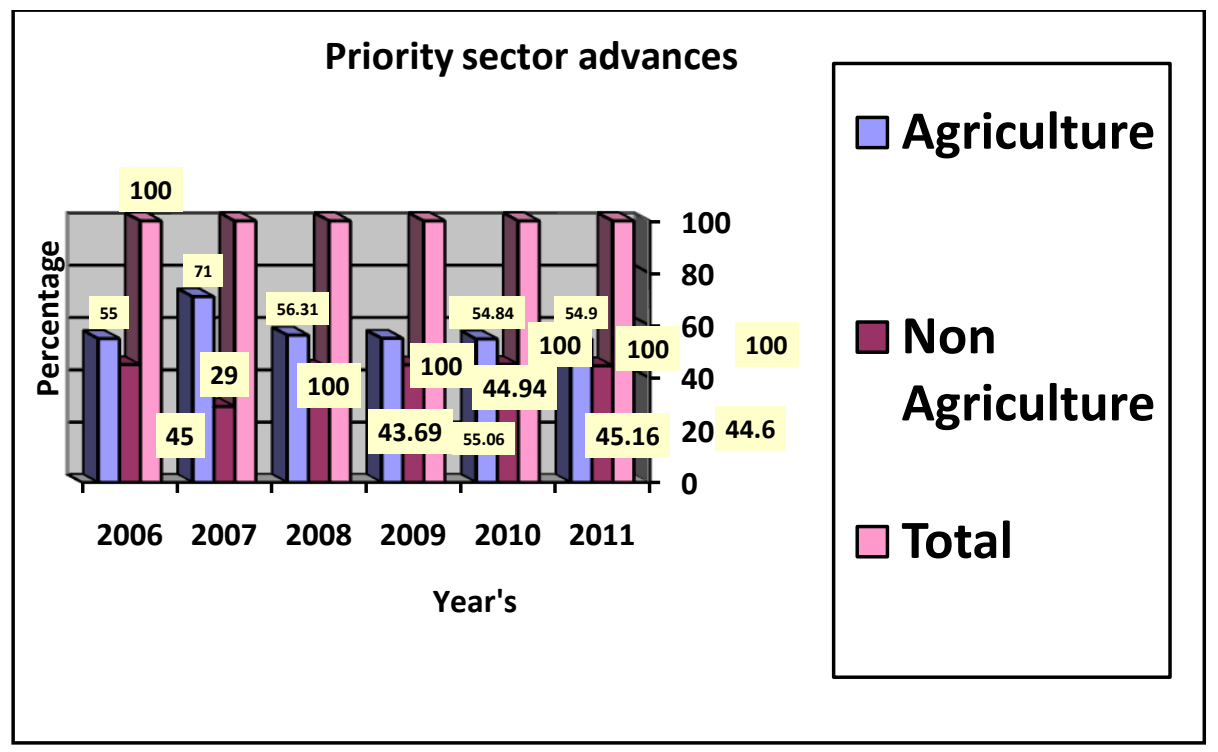

Fig. 1

Source: RBI Report on trend \& progress of Banking in India 


\section{Regionwise Gross NPAs}

It is examined from Table-7 that the RRBs have faced a serious problem of mounting up of NPA's which were $7.28 \%$ during the year 2006, which affected the profitability of RRB's.

Table 7: Regionwise Gross NPA’s (in \%)

\begin{tabular}{|l|c|c|c|c|c|}
\hline \multirow{2}{*}{ Zone } & \multicolumn{5}{|c|}{ Year } \\
\cline { 2 - 6 } & $2005-6$ & $2006-7$ & $2007-8$ & $2008-9$ & $2009-10$ \\
\hline NER & 15.76 & 16.02 & 5.89 & 18.5 & 10.7 \\
\hline North & 4.2 & 21.08 & 3.17 & 5.4 & 46.88 \\
\hline Central & 19.07 & 8.46 & - & 4 & 45.8 \\
\hline South & 19.61 & 32.21 & - & 0.85 & 35.5 \\
\hline West & 15 & 25.5 & 8.72 & 21 & 18 \\
\hline East & 10.42 & 4.88 & 1.1 & 0.44 & 40 \\
\hline India & 14.35 & 12.75 & 2.5 & 7.6 & 39.5 \\
\hline
\end{tabular}

Source; RBI Report on trend \& progress of Banking in India

Thus the reduction of NPA's has posed the biggest challenge to RRB's. Consolidation of RRBs resulted in reducing NPA's from $7.28 \%$ to $3.66 \%$ for 2010 .Further it shows that NER RRBs improved NPA's from $13.73 \%$ to $6.53 \%$ followed by southern banks, central and eastern RRBs $(4.57 \%, 4.16 \%$ and $6.75 \%)$.

Table 8: Regionwise Recovery as on 30 June 2010 ( Growth in \%)

\begin{tabular}{|l|l|l|l|l|l|}
\hline \multirow{2}{*}{ Zone } & \multicolumn{5}{|c|}{ Year } \\
\cline { 2 - 6 } & 2006 & 2007 & 2008 & 2009 & 2010 \\
\hline NER & 11.07 & 1.99 & 2.41 & 7.29 & 26.2 \\
\hline North & 2.82 & 0.056 & 3.85 & 2.21 & -13.95 \\
\hline Central & 0.32 & -0.63 & -1.18 & -1.44 & 8.33 \\
\hline South & 0.82 & 4.01 & -0.93 & 1.16 & -7.2 \\
\hline West & 3.78 & 1.24 & -0.90 & 0.56 & -8.5 \\
\hline East & 2.70 & -1.53 & -2.60 & 5.32 & -7.9 \\
\hline India & 2.81 & 00 & -2.5 & 1.63 & -3.03 \\
\hline
\end{tabular}


A remedial measure taken by RRBs to reduce NPA's through recovery of loans outstanding. From the above table: 8 , it is found that recovery performance of RRBs during 2006 was $2.81 \%$ and it was negative to $-3.03 \%$ during 2011. The region wise recovery performance of Northern Eastern and Central region banks was positive, whereas others showed negative value.

\section{Credit Deposit Ratio}

Table 9: Credit Deposits Ratio of RRBs in India

\begin{tabular}{|c|c|c|}
\hline Years & CD Ratio (\%) & Growth \% \\
\hline $2005-06$ & 55.70 & 5.49 \\
\hline $2006-07$ & 58.3 & 4.67 \\
\hline $2007-08$ & 59.5 & 2.06 \\
\hline $2008-09$ & 56.4 & -5.21 \\
\hline $2009-10$ & 57.6 & 2.13 \\
\hline $2010-11$ & 59.69 & 3.62 \\
\hline
\end{tabular}

Source: NABARD Annual report

It was found from Table-9, that the percentage growth of credit deposit ratio of the RRBs during the study period was fluctuating, it was $5.49 \%$ for the year 2006, which decreased to $4.67 \%$ for 2007 . There was negative growth for 2009and increased during 2010, again it decreased to $3.62 \%$ during 2011.

Table 10: Comparison between Deposits and Advances (Rs In crore)

\begin{tabular}{|c|c|c|}
\hline Years & Deposits & Advances \\
\hline 2006 & 71329 & 38520 \\
\hline 2007 & 83144 & 47326 \\
\hline 2008 & 99093 & 57568 \\
\hline 2009 & 120189 & 65609 \\
\hline 2010 & 145035 & 79157 \\
\hline 2011 & 166232 & 101039 \\
\hline
\end{tabular}

Source: NABARD Annual report

It was found from the above table 10, that the increase in deposits leads to relative increase in the advances over the six years under the study. 
Table 11: Statistics of RRB'S

\begin{tabular}{|c|c|c|c|}
\hline Indicator & Mean & $\begin{array}{c}\text { Standard } \\
\text { Deviation }\end{array}$ & Correlation \\
\hline Deposits & 114170.3 & 0.3944 & \multirow{2}{*}{0.998} \\
\hline Advances & 68869.88 & 0.20968 & \\
\hline
\end{tabular}

Source: Calculated from Table 10

Physical performance of RRBs is examined by studying the datas of six years after amalgamation, average deposits were Rs 11,14,170.33 crores and advances Rs 6,88,69.88 crores respectively.An attempt made to analyze the direction of change and relationship among deposits and advances of the bank. For this analysis, researcher worked on correlation of deposits and advances of the bank over the study period. There is a positive correlation of 0.998 (see Table: 11) and concluded that there is a significant correlation between deposits and advances.

\section{Conclusion}

In the present study of the performance of RRB'S, an attempt has been made to analyze the performance in terms of defined parameters like, spread of branches, profit/loss making units, mobilization of deposits, NPA's and recovery performance. The performance of RRBs in India improved during the post amalgamation period, even though number of RRBs reduced; there has been increase in profitability. There has been improvement in deposit mobilization and credit deployment, recovery performance and decrease in NPA's. It was found that CD ratio of RRBs was fluctuating. However, it is the responsibility of the bank management and sponsor banks to take corrective steps to raise CD-ratio. Apart from this RRBs should extend their service to unbanked areas, personal loans to rural artisans and small-scale industries.

\section{References}

Bagachi, K. K., \& Hadi, A. (2006). Performance of regional rural banks in West Bengal: An evaluation. West Bengal: Serials Publications. 
Banker, R. D., Charnes, A., \& Cooper, W. W. (1984). Some models for estimating technical and scale inefficiencies in data envelopment analysis. Management Science, 30(9), 1078-1092.

Bhat, N., \& Thorat, Y. S. P. (2001). India's regional rural bank: The institutional dimension of reforms. Journal of Microfinance, 31(1), 65-88.

Ishwara, P. (2011). India- a financial performance analysis of RRBs: Pre and post transformation. International Journal of Economic Research, 2(1), 141-151.

Prasad, T. S. (2003). Regional rural banks: Performance evaluation. Kurukshetra, 51(10), 20-24.

Versa, M., \& Gian, K. (2011). Efficiency of regional rural banks in India: An application of data envelopment analysis. Economic Affairs, 56(2), 189-198. 